\section{ECONOMICS}

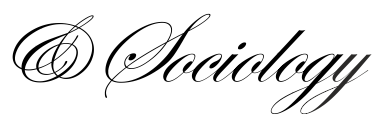

Vo, H. D. (2020). Sustainable agriculture \& energy in the U.S.: A link between ethanol production and the acreage for corn. Economics and Sociology, 13(3), 259268. doi:10.14254/2071-789X.2020/13-3/16

\title{
SUSTAINABLE AGRICULTURE \& ENERGY IN THE U.S.: A LINK BETWEEN ETHANOL PRODUCTION AND THE ACREAGE FOR CORN
}

\section{Duc Hong Vo \\ Ho Chi Minh City Open \\ University, Ho Chi Minh City, \\ Vietnam \\ E-mail:duc.vbong@ou.edu.vn \\ ORCID 0000-0001-7823-0349}

Received: December, 2019

1st Revision: June, 2020

Accepted: September, 2020

DOI: $10.14254 / 2071-$

789X.2020/13-3/16
JEL Classification: Q11, Q18, Q24
ABSTRACT. The world has been witnessing the dual crises from the Covid-19 pandemic since 2019: (i) the economic crisis; and (ii) the health crisis. During crisis, it is important to revisit the sustainability of two of the most important policies on agriculture and energy for any country. Corn has played an increasingly important role in the U.S. agricultural market. As of 2018, corn accounts for about 95 per cent of the U.S. total feed grain. As such, corn is generally placed at the centre of the policies on agriculture in the U.S. The primary reason for the rise in corn production and use is due to the expansion of ethanol production. This expansion pushes corn prices to increase and provides an incentive for people to enlarge corn acreage. In addition, ethanol production has rapidly expanded over the last few decades in the U.S. Corn ethanol is expected to be a viable alternative for oil. We consider that the expansion of ethanol and corn production has many consequences. Corn price and the prices of many agricultural commodities have dramatically increased during the last decade. In this paper, the Auto Regressive Distributed Lags (ARDL) technique together with the bounds test and the estimation of short-run and long-run elasticity are utilized for the 1980-2018 period using the U.S. data. Empirical results from our paper confirm the long-run relationships between corn used in ethanol and the acreage for corn. In addition, results from our analyses support the view that the expansion of corn ethanol is a key reason behind the increase in corn acreage. We also consider that the increase in demand for corn used in ethanol production is more likely to affect the acreage. This finding implies the important role of ethanol production and expansion in the change of land use in the U.S.

Keywords: corn, bio-ethanol production, acreage, auto-regressive distributed lags, sustainable agriculture \& energy, The U.S. 


\section{Introduction}

Corn has played an increasingly important role in the U.S. agricultural market. As of 2018, corn accounts for about 95 per cent of the U.S. total feed grain. Corn acreage has grown 1.5 times to over 90 million since the 1980s (Wald, 2018). The increase is largely due to a spike in the number of large corn farms, while small corn farms had been reduced significantly. The primary reason for the rise in corn production and its use is the expansion of the ethanol production, which pushes corn prices to increase and incentivizing people to enlarge corn acreage. However, with most cultivated farmland already used to plant other crops, finding ways to increase corn acreage may be a challenging task. A few approaches have been initiated to increase land for corn planting, including adjusting crop rotations between corn and soybeans, using cropland as pasture and reduced fallow. The ethanol industry in the U.S. has been growing rapidly in recent decades. The number of biofuel refineries had grown fourfold since 1999. However, during the last few years, the ethanol industry has had a bit of a drawback with many people calling for a reduction in ethanol production in fear of pollution. In 2019, 20 ethanol plants in the U.S. got closed down, resulting in 300-million-gallon reduction compared to 2018. Despite the decline, the ethanol industry still had positive contributions to the U.S.'s economy with $\$ 23.3$ billion in household income and 68,000 direct jobs and overall contributed $\$ 43$ billion to the national GDP (Renewable Fuels Association, 2020).

The U.S. economy has become steadily less energy-intensive. In 1949, it took 15,175 Btu to generate each dollar of real gross domestic product, while in 2018, it only took 5,450. Per capita energy use in the U.S. had also been trending down since the 21 st century. On average, each American in 2000 used about 349.8 million Btu. By 2017 that had fallen to 300.5 million Btu, the lowest figure in five decades (Desilver, 2020; Pham and Vo, 2017). The U.S. energy market had seen a great transformation in the past few decades. The use of energy in the U.S. has become more efficient, with only 5,450 Btu needed to generate one dollar of real GDP in 2018, as compared to three times that amount in the 1950s. In 2017, per capita energy use had also gone down 14 per cent since 2000, marking its lowest point in decades (Desilver, 2020).

Fossil fuels still play a dominant role in the U.S. energy structure, accounting for 79 per cent of the country energy sources. Within fossil fuels, crude oil and natural gas are gaining importance, taking up 80 per cent of total production. At the same time, coal has declined quickly, from nearly 35 per cent in 2008 to only 16 per cent of total domestic energy production in 2018. Renewable energy is a distant second behind fossil fuels, accounting for 12 per cent of total energy production. Among them, hydropower is the biggest renewable source, followed by wind, wood and biofuels. Solar energy has witnessed the largest growth out of any energy source in the U.S. From 2008 to 2018, the total electricity generated by solar power increased nearly 46 times, from over 2 billion to 93 billion kilowatt-hours. Nonetheless, solar still contributed very little to the U.S.'s total energy production, accounting for about 1 per cent in 2018 (Desilver, 2020).

Although corn ethanol is expected to be a viable alternative for oil, the expansion of ethanol and corn production has many consequences (Vu et al., 2020). Corn price and the prices of many agricultural commodities have dramatically increased during the last decade. Ethanol subsidies and market demand for ethanol are responsible for 20 per cent of the increase in corn price during 2007-2008 (Gecan et al., 2009) and 36 per cent during 2006-2009 (Babcock and Fabiosa, 2011). Various studies show that agricultural prices tend to be correlated to crude oil price after the growth of biofuel (Chang et al., 2018; Su et al., 2019; Vo et al., 2019). The correlation is considered one of the main reasons leading to the recent food price crisis.

Multinational corporations and modern technology have a significant but complex role in ethanol implication, food security and the development of the agricultural sector. On the one 
hand, multinational corporations have a positive effect on the development of the agricultural sector through large investments on modern technologies to improve agricultural productivity and to promote the commercialization of the second generation of biofuel which does not use food crops for energy generation (K. Fuglie, 2016; K. O. Fuglie, 2016; Sims et al., 2010). Both activities tend to reduce the negative effect of ethanol expansion on food security. On the other hand, multinational corporations can have a negative effect on agricultural development and food security through land grabbing. Researchers found that FDI inland of investors from developing countries may lead to negative environmental spillovers such as water pollution and soil degradation, which reduce cropland and agricultural yields (Constantin et al., 2017; Santangelo, 2018). Moreover, agricultural modernization and mechanization increase the dependence on energy consumption, which can exacerbate the food crisis when fossil fuel prices increase (Baumeister and Kilian, 2014).

This paper is conducted to examine and investigate the impact of ethanol expansion on the planted acreage. Bor and Bayaner (2009) consider that farmers often decide the level of production based on harvest crop prices. We argue that corn ethanol may be a key reason behind the increase in corn acreage albeit other reasons such as the harvest prices, such as adverse weather conditions, changes in exchange rates or increase in energy prices (Fox et al., 2011; Mitchel, 2008; Wallander et al., 2011).

\section{Literature review}

Findings from various studies consider that ethanol expansion has led to an increase in corn production. Li et al. (2019) examined the effects of ethanol plant proximity and crop prices on cropland acreage using a nationwide panel data of 2535 counties in the U.S. during the period 2003 - 2014. The study focused on analyzing the direct effects of corn ethanol production on land use in its vicinity without explicitly controlling for the effect of crop prices. Empirical findings indicated that corn ethanol production had a positive and statistically significant direct effect on corn acreage and aggregate cropland acreage at the county level. However, the effects were reversed by the drop in crop prices around 2012. Feng and Babcock (2010) developed an economic framework to assess the land-use impacts of biofuels. The authors analyzed land-use changes in ethanol expansion with mediating roles from ethanol production, acreage allocation, and crop markets. Two drivers behind land-use changes were examined: (i) government subsidies for ethanol and (ii) government mandates on the quantity of ethanol use. They had opposing effects on cropland yield, with subsidies inducing more land used for planting production, while mandates caused a decrease in total cropland.

In contrast, Shrestha, Staab, and Duffield (2019) find that there is no significant landuse change caused by the expansion of corn ethanol. The authors investigate the correlations between biofuel production and food prices or land-use changes in the U.S. from 1973 to 2016. The authors compared the food price index before and after the biofuel boom in the 2000s to evaluate biofuel's impact on the inflation rate. Empirical findings failed to confirm the difference in CPI for food between the periods. Crude oil was discovered to be highly correlated with the increase in food prices. Finally, even though there was evidence of land-use change in a satellite image, the difference was determined to be within the margin of error. Motamed et al. (2016) measured corn and total agricultural area in the United States from 2006 to 2010. Using grid cell data, acreage in corn and overall agriculture were found to grow in alreadycultivated areas and develop into uncultivated areas. Acreage in corn and total agriculture both had a high correlation with ethanol plants proximity; however, the impact diminished over time.

In a recent paper, Katchova and Sant'Anna (2019) examine the effects of ethanol plant location on corn revenues in the U.S. Analyzing the 2015 and 2016 rounds of the USDA Agricultural Resource Management Survey using spatial difference-in-differences. Findings 
from this paper fail to confirm a statistically significant effect of ethanol plant location on corn contract revenues with the focus on the same county. However, findings from this paper provide evidence to confirm the effect of ethanol plant location on corn contract revenues with the focus on the adjacent counties. The authors note that revenues are higher in the regions with the presence of ethanol plants. As such, they conclude that the main factor for the high revenues in these regions is due to the local competitive advantage. Fatal and Thurman (2014) argue that from 2002 to 2008, the ethanol production capacity in the U.S. increased more than threefold. The authors aim to explore the impact of such acceleration on corn acreage. Using data from the Renewable Fuel Association for approximately 143 plants, findings from their paper indicate that a typical plant which is built in the county can increase corn in the same region by over more than 500 acres. These newly built plants can also increase acreage in surrounding counties.

The brief overview of biofuel production shows various consequences on agricultural commodities throughout several aspects such as planted acreage or crop price. However, the response of agriculture acreage or price to corn ethanol production is ambiguous. On the one hand, no significant relationship between corn ethanol production and planted acreage has been found (Shrestha, Staab, and Duffield, 2019; and Katchova and Sant'Anna, 2019). On the other hand, corn ethanol production has been confirmed to provide an effect on corn acreage or agricultural acreage (Li et al., 2019; and Fatal and Thurman, 2014). In addition, government invention has also provided mixed effects on the relationship between ethanol production and planted acreage (Feng and Babcock, 2010). Previous studies have utilized panel data analysis to examine the response of planted acreage and agricultural commodity price to ethanol production ( $\mathrm{Li}$ et al., 2019; and Katchova and Sant'Anna, 2019). The panel data analysis has several advantages. First, a panel data forms a relatively larger sample in comparison with cross-sectional or time-series data. Second, a large sample allows the addition of more control variables into the model to take into account potential effects from various factors. However, panel data also exhibit limitations. Panel data is usually employed to capture a short-term correlation between variables. Endogeneity is generally considered a critical issue in a panel data analysis. On the other hand, a time-series analysis is usually an alternative to a panel technique to mitigate the potential endogenous problems (Menegaki, 2019). In particular, the ARDL model, which is adopted in this study, provides superior advantages for the current study. The ARDL model can perform well with a small sample which is a typical problem of time-series analysis at the aggregated level. Second, the optimal lag of variables in the model helps mitigate the biased estimations caused by the potential problem of endogeneity (Vo et al., 2020).

On the above considerations, our study contributes to the current study on the following two aspects. First, we directly examine the relationship between corn ethanol production and corn planted acreage in the U.S. Second, we utilize a time-series analysis in the current study to overcome a potential problem of endogeneity. Furthermore, we employ the ARDL model to examine the response of corn planted acreage to corn ethanol production in both long-term and short-term horizons.

\section{Methodological approach}

\subsection{Conceptual framework}

Previous studies show that agricultural supplies respond to price and non-price factors. As farmers have an incentive to allocate their resources to the most profitable crops, agricultural supplies will respond to price fluctuation of agricultural products (Powell et al., 2018, 2019). On the other hand, non-price factors, such as rural infrastructure, access to credit, weather 
conditions and soil fertility can affect inputs, the efficiency, and yields of agricultural production (Thiele, 2000). In relation to the price factors, previous studies often use variations of the Nerlovian model to estimate the price elasticity of agricultural supply. According to Thiele (2000), these models have two major disadvantages. First, they tend to bias the estimated elasticities downward due to the restrictive assumption that ties the current output to the longrun desired supply. Second, the OLS estimator is spurious if the variables are non-stationary (McKay et al., 1999).

Using time-series methods, such as Error Correction Models (ECMs), can avoid the problem of spurious regression (Hallam and Zanoli, 1993; Thiele, 2000). The three types of ECMs include Engle-Granger approach, Vector Error Correction models (VECM), and AutoRegressive Distributed Lags (ARDL). We argue that the ARDL approach can overcome the problem of mixed stationarity and only requires a small data sample (Vo et al., 2020). Huq and Arshad (2010) point out that agricultural supplies are susceptible to uncertainties such as weather conditions while the area is more likely to reflect farmers' planned output. As the study focuses on the impact of ethanol expansion on farmers' production decision, we decide to use planted acreage as dependent variables instead of agricultural supply. Based on the review of previous studies, we incorporate the following variables in a general ARDL model to estimate the acreage response of corn, in the U.S.:

$$
\ln C A_{t}=\gamma_{1}+\sum_{\mathrm{i}=1}^{\mathrm{m}} \ln C A_{t-1}+\sum_{\mathrm{i}=1}^{\mathrm{n}_{1}} \ln C E_{t-1}+\sum_{\mathrm{i}=1}^{\mathrm{n}_{2}} \ln C P_{t-1}+\varepsilon_{1 t}
$$

where $C A_{t}$ is the planted acreage of corn, $C P_{t}$ is corn price received by farmers, $C E_{t}$ is the corn used in ethanol production. $m$ is the optimal lag length for the dependent variables, while $n_{1}$ and $n_{2}$ are the optimal lag length for the explaining variables. In equation (1), we are concerned about the impact of ethanol expansion on the planted acreage of corn.

\subsection{Bounds test}

To apply the ARDL bounds test approach to co-integration, we re-parameterize equations (1)-(2) to obtain their unrestricted ECM specification:

$$
\begin{aligned}
\Delta \ln C A_{t}=\alpha_{11}+ & \alpha_{12} \ln C A_{t-1}+\alpha_{13} \ln C P_{t-1}+\alpha_{14} \ln C E_{t-1}+\alpha_{15} \ln C E_{t-1}^{2} \\
& +\sum_{\substack{i=1 \\
n_{1}}}^{m} \beta_{1 i} \Delta \ln C A_{t-i}+\sum_{i=1}^{n_{2}} \beta_{2 i} \Delta \ln C P_{t-i}+\sum_{i=1}^{n_{3}} \beta_{3 i} \Delta \ln C E_{t-i}+\sum_{i=1} \Delta \ln C E_{t-i}^{2} \\
& +\varepsilon_{1 t}
\end{aligned}
$$

Where $\Delta$ is the difference operator, the number of lags is based on the Akaike information criterion. Ramsey RESET test provides evidence that equation (2) would be incorrectly specified without the squared term of corn ethanol production. Equation (2) tests the long-run relationship between corn area, corn price and corn ethanol.

\subsection{Long-run and short-run supply elasticities}

After confirming the existence of the long-run relationship between the variables, we estimate the long-run land elasticities using the following ARDL models.

$$
\ln C A_{t}=\omega+\sum_{j=1}^{m} \theta_{1 j} \ln C P_{t-j}+\sum_{j=1}^{n_{1}} \theta_{2 j} \ln C E_{t-j}+\sum_{j=1}^{n_{2}} \theta_{3 j} \ln C E_{t-j}^{2}+\varepsilon_{t}
$$

where $\theta$ represents the long-run elasticities of these variables with respect to the planted acreage. The optimal lag length is chosen according to the Akaike information criterion. Equation (3) measures the long-run elasticity of corn area with respect to corn ethanol. 
We estimate the short-run elasticities by using the following restricted ECM specifications. As the short-run movements of the variables tend to deviate from the long-run equilibrium, this procedure measures how long it takes for the short-term disequilibrium to adjust toward the long-run state:

$\Delta \ln C A_{t}$

$=\sigma+\sum_{k=1}^{m} \rho_{1 j} \Delta \ln C A_{t-k}+\sum_{k=1}^{n_{1}} \rho_{2 j} \Delta \ln C P_{t-k}+\sum_{k=1}^{n_{2}} \rho_{3 j} \Delta \ln C E_{t-k}+\sum_{k=1}^{n_{3}} \rho_{4 j} \Delta \ln C E_{t-k}^{2}+\pi E C T_{t}$

$+\varepsilon_{t}$

where: $\rho$ represents the short-run elasticities of these variables. The speed of adjustment to the long-run equilibrium is measured by coefficient $\boldsymbol{\pi}$ of the Error Correction Terms (ECT).

\section{Data and empirical results}

\subsection{Data}

In this paper, the 1980-2018 period is considered. We collect data for planted acreage and agricultural commodity prices received by farmers. The quantity of corn used in ethanol production is collected from the Feed Grains Database, Economic Research Service, and the United States Department of Agriculture (USDA). The nominal prices received by farmers are deflated using the CPI to obtain the real prices. The CPI data are collected from the Federal Reserve Bank of St. Louis.

\subsection{Unit root tests}

Empirical results of the unit root test based on the augmented Dickey-Fuller (ADF) and Kwiatkowski-Phillips-Schimdt-Sin (KPSS) respectively are presented in Table 1 and Table 2 below. The ADF statistics with constant and no trend show that all the variables are stationary at the first difference. For the ADF with constant and trend, at the first difference, ADF statistics show that all variables are stationary at 5 per cent significance level. In addition, the results of the KPSS test with constant and no trend show that we cannot reject the null hypothesis of stationary for all variables at the first difference.

Table 1. ADF tests

\begin{tabular}{llcccc}
\hline & & \multicolumn{2}{c}{ ADF with constant and no trend } & \multicolumn{2}{c}{ ADF with constant and trend } \\
\hline Series & Forms & Test statistics & Conclusion & Test statistics & Conclusion \\
\hline $\begin{array}{l}\text { Log } \\
\text { (Corn area) }\end{array}$ & Level & -2.89 & $\mathrm{I}(1)$ & -4.98 & $\mathrm{I}(0)$ \\
\hline \multirow{nyyyyy}{*}{$\begin{array}{l}\text { Fog } \\
\text { (Corn price) }\end{array}$} & Level & -9.09 & $\mathrm{I}(0)$ & -8.76 & $\mathrm{I}(0)$ \\
\hline \multirow{nyyyyy}{*}{$\begin{array}{l}\text { Log } \\
\text { Corn ethanol) }\end{array}$} & First differences & -2.83 & $\mathrm{I}(1)$ & -2.66 & $\mathrm{I}(1)$ \\
\cline { 2 - 6 } & Level & -5.66 & $\mathrm{I}(0)$ & -5.59 & $\mathrm{I}(0)$ \\
\hline
\end{tabular}

The ADF and KPSS results suggest that there is a mixture of stationary $\mathrm{I}(0)$ and unit root I(1) variables. There is no evidence that the variables are integrated of order 2 . In this case, we decide to use the Auto Regressive Distributed Lags approach to estimate the long run and short-run elasticity. 
Table 2. KPSS tests

\begin{tabular}{llcccc}
\hline & & \multicolumn{2}{c}{ KPSS with constant and no trend } & \multicolumn{2}{c}{ KPSS with constant and trend } \\
\hline Series & Forms & Test statistics & Conclusion & Test statistics & Conclusion \\
\hline \multirow{2}{*}{$\begin{array}{l}\text { Log } \\
\text { Corn area })\end{array}$} & Level & 0.50 & $\mathrm{I}(1)$ & 0.17 & $\mathrm{I}(1)$ \\
\hline \multirow{2}{*}{$\begin{array}{l}\text { Fog } \\
\text { Corn price) })\end{array}$} & Level & 0.19 & $\mathrm{I}(0)$ & 0.12 & $\mathrm{I}(0)$ \\
\hline \multirow{2}{*}{$\begin{array}{l}\text { Log } \\
\text { (Corn ethanol })\end{array}$} & First differences & 0.12 & $\mathrm{I}(0)$ & 0.13 & $\mathrm{I}(0)$ \\
\cline { 2 - 6 } & Level & 0.38 & $\mathrm{I}(0)$ & 0.06 & $\mathrm{I}(0)$ \\
\hline
\end{tabular}

\subsection{Bounds testing}

Table 3 presents that corn ethanol tends to have a stronger relationship with the prices compared to corn area because the results of the ARDL bounds test confirm the long-run relationship between the series at 5 per cent significance level.

Table 3. A bounds testing

\begin{tabular}{llcccc}
\hline $\begin{array}{l}\text { Dependent } \\
\text { variables }\end{array}$ & Regressors & $\begin{array}{c}\text { F-statistics } \\
\text { value }\end{array}$ & $\begin{array}{c}\text { The lower bound } \\
\text { value I(0) }\end{array}$ & $\begin{array}{c}\text { Upper bound } \\
\text { value I(1) }\end{array}$ & Result \\
\hline $\begin{array}{l}\text { The corn price, } \\
\text { Corn area }\end{array}$ & $\begin{array}{l}\text { Corn ethanol, } \\
\text { Corn ethanol } \\
\text { squared }\end{array}$ & 21.94 & 3.23 & 4.35 & $\begin{array}{c}\text { Co- } \\
\text { integration }\end{array}$ \\
\hline
\end{tabular}

\subsection{Long-run and short-run equilibrium elasticities of corn acreage}

Table 4 shows the results of the long-run elasticities of the corn equation. The results of ARDL $(2,1,1,1)$ suggests that a 10 per cent increase in corn price received by farmers will increase the planted acreage of corn by 0.6 per cent. Corn ethanol also has a positive impact on corn area, meaning that a 10 per cent increase in corn demand for ethanol production will increase corn area by 3.2 per cent.

Table 4. Long-run equilibrium elasticity between corn acreage, corn price and corn ethanol

\begin{tabular}{lccc}
\hline Variables & Coefficient & Standard error & Probability \\
\hline Corn price & $0.06^{*}$ & 0.03 & 0.09 \\
\hline Corn ethanol & $0.32^{*}$ & 0.17 & 0.07 \\
\hline Corn ethanol squared & -0.02 & 0.01 & 0.17 \\
\hline $\mathrm{C}$ & $2.87^{* * *}$ & 0.64 & 0.00 \\
\hline$*$ and $* * *$ are significant at 10 and 1 per cent, respectively & & \\
\hline
\end{tabular}

Table 5 reports the results of short-run elasticities. Corn ethanol has a positive and significant effect on corn area planted. However, corn ethanol squared has a negative impact on corn area. The effect is significant. The results suggest that even though the expansion of corn ethanol has a positive impact on corn acreage, such effect diminishes when corn ethanol increases.

Table 5. Short-run equilibrium elasticity between corn area, corn price and corn ethanol

\begin{tabular}{lccc}
\hline Variables & Coefficient & Standard error & Probability \\
\hline D(Corn area) & 0.19 & 0.14 & 0.18 \\
\hline $\mathrm{D}$ (Corn price) & -0.08 & 0.05 & 0.11 \\
\hline $\mathrm{D}$ (Corn ethanol) & $1.67^{* * *}$ & 0.56 & 0.01 \\
\hline $\mathrm{D}$ (Corn ethanol squared) & $-0.11^{* *}$ & 0.05 & 0.02 \\
\hline ECT(-1) & $-1.16^{* * *}$ & 0.22 & 0.00 \\
\hline Adjusted R-squared & & 0.82 \\
\hline Breusch-Godfrey Serial Correlation L.M. p-value & & 0.79 \\
\hline
\end{tabular}




\begin{tabular}{lc}
\hline Breusch-Pagan-Godfrey p-value & $0.04^{* *}$ \\
\hline Jarque-Berra p-value & 0.14 \\
\hline Ramsey reset stat p-value & 0.10 \\
\hline \multicolumn{2}{c}{$* *$ and $* * *$ are significant at 10, and 5 per cent, respectively } \\
\hline
\end{tabular}

\section{Conclusions}

This paper is conducted to examine and investigate the response of agricultural planted acreage to crop prices and corn used in ethanol production in the U.S. for the 1980-2018 period. We use the ARDL approach with bounds test and estimate the short-run and long-run elasticities. Findings from our analysis indicate the long-run relationships between corn used in ethanol and crops acreage. In addition, empirical findings from the paper present that the expansion of corn ethanol is a key reason behind the increase in corn acreage. Moreover, the increase in demand for corn used in ethanol is more likely to influence the planted acreage. This suggests the important role of ethanol expansion in the land-use change.

The above findings lead to some observations for implications which are discussed in turn below. Since 2011, the Environmental Protection Agency (EPA) has been fixated on preventing seasonal selling a blend of gasoline with a high proportion of ethanol which is generally called E15. For years, ethanol gasoline has received a strong push back for allegedly polluting the environment. In fact, since 2011, the Environmental Protection Agency (EPA) has banned the selling of E15, the type of gasoline with a high level of ethanol, between June and September annually. On top of that, the agency has consistently exempted small refineries, undermining the renewable fuel capacity by as much as 4 billion gallons for the period 2016-2018 (Renewable Fuels Association, 2020). However, at the end of 2018, there was a turnaround in the U.S. policy on ethanol-gasoline with the lifting of the E15 ban. Moreover, incentives for the production and consumption of E15 were also introduced, including streamlining labels and providing financial aid to research projects exploring higher ethanol blends. As for the renewable fuel volume loss, the EPA has decided to reallocate it to the following compliance years. Annual quota on corn starch-based ethanol has also been established by the U.S. Congress. The policies are expected to increase near-future ethanol demand by 40 million gallons.

\section{Acknowledgement}

This research is funded by Ho Chi Minh City Open University Vietnam under the grant number [E2019.23.3].

\section{References}

Babcock, B. A., \& Fabiosa, J. F. (2011). The impact of ethanol and ethanol subsidies on corn prices: revisiting history, Card Policy Briefs, Iowa State University.

Baumeister, C., \& Kilian, L. (2014). Do oil price increases cause higher food prices? Economic Policy, 29(80), 691-747.

Bor, O., \& Bayaner, A. (2009). How Responsive is the Crop Yield to producer prices? A panel data approach for the case of Turkey. New Medit, 8(4), 28-33.

Chang, C.-L., Li, Y., \& McAleer, M. (2018). Volatility spillovers between energy and agricultural markets: A critical appraisal of theory and practice. Energies, 11(6), 1595.

Constantin, C., Luminița, C., \& Vasile, A. J. (2017). Land grabbing: A review of extent and possible consequences in Romania. Land Use Policy, 62, 143-150. 
Desilver, D (January 15, 2020). Fossil fuels still dominate U.S. energy, but renewables growing fast. Pew Research Center. Retrived from: https://www.pewresearch.org/facttank/2020/01/15/renewable-energy-is-growing-fast-in-the-u-s-but-fossil-fuels-stilldominate/

Fatal, Y. S., \& Thurman, W. N. (2014). The Response of Corn Acreage to Ethanol Plant Siting, Journal of Agricultural and Applied Economics 46(2), https://doi.org/10.22004/AG.ECON.168993

Feng, H., \& Babcock, B. A. (2010). Impacts of ethanol on planted acreage in market equilibrium. American Journal of Agricultural Economics, 92(3), 789-802. https://doi.org/10.1093/ajae/aaq023

Fox, J. F., Fishback, P. V, \& Rhode, P. W. (2011). The effects of weather shocks on crop prices in unfettered markets: The united states prior to the farm programs, 1895-1932. In The Economics of Climate Change: Adaptations Past and Present, 99-130, University of Chicago Press.

Fuglie, K. (2016). The growing role of the private sector in agricultural research and development world-wide. Global Food Security, 10, 29-38.

Fuglie, K. O. (2016). Investing in agricultural productivity in Indonesia. Forum Penelitian Agro Ekonomi, 17(2), 1-16.

Gecan, R., Johansson, R., \& FitzGerald, K. (2009). The impact of ethanol use on food prices and greenhouse-gas emissions. the U.S.'s Congressional Budget Office.

Hallam, D., \& Zanoli, R. (1993). Error correction models and agricultural supply response. European Review of Agricultural Economics, 20(2), 151-166.

Huq, A., \& Arshad, F. M. (2010). Supply response of potato in Bangladesh: A vector error correction approach. Journal of Applied Sciences, 10(11), 895-902.

Katchova, A. L., \& Sant'Anna, A. C. (2019). Impact of Ethanol Plant Location on Corn $\begin{array}{llll}\text { Revenues for U.S. Farmers. Sustainability, } & 11(22), \quad 6512 .\end{array}$ https://doi.org/10.3390/su11226512

Li, Y., Miao, R., \& Khanna, M. (2019). Effects of ethanol plant proximity and crop prices on land-use change in the United States. American Journal of Agricultural Economics, 101(2), 467-491. https://doi.org/10.1093/ajae/aay080

McKay, A., Morrissey, O., \& Vaillant, C. (1999). Aggregate supply response in Tanzanian agriculture. Journal of International Trade \& Economic Development, 8(1), 107-123.

Menegaki, A. N. (2019). The ARDL Method in the Energy-Growth Nexus Field; Best Implementation Strategies. Economies, 7(4), 105. https://doi.org/10.3390/economies7040105

Mitchel, D. (2008). A note on rising food prices. The World Bank.

Motamed, M., McPhail, L., \& Williams, R. (2016). Corn area response to local ethanol markets in the United States: A grid cell level analysis. American Journal of Agricultural Economics, 98(3), 726-743. https://doi.org/10.1093/ajae/aav095

Powell, R. J., Vo, D. H., \& Pham, T. N. (2018). Economic cycles and downside commodities risk. Applied Economics Letters, 25(4), 258-263. https://doi.org/10.1080/13504851.2017.1316818

Powell, R., Vo, D. H., \& Pham, T. N. (2019). Cattle as a consistently resilient agricultural commodity. Applied Economics, 51(55), 5911-5922. https://doi.org/10.1080/00036846.2019.1631441

Santangelo, G. D. (2018). The impact of FDI in land in agriculture in developing countries on host country food security. Journal of World Business, 53(1), 75-84.

Shrestha, D. S., Staab, B. D., \& Duffield, J. A. (2019). Biofuel impact on food prices index and land use change. Biomass and Bioenergy, 124, 43-53. 
Sims, R. E. H., Mabee, W., Saddler, J. N., \& Taylor, M. (2010). An overview of second generation biofuel technologies. Bioresource Technology, 101(6), 1570-1580.

Su, C. W., Wang, X.-Q., Tao, R., \& LobonT,, O.-R. (2019). Do Oil Prices Drive Agricultural Commodity Prices? Further Evidence in a Global Bio-energy Context. Energy, 172, 691701.

Thiele, R. (2000). Estimating the aggregate agricultural supply response: A survey of techniques and results for developing countries. Kiel Working Paper.

Vo, D. H., Vo, A. T., Ho, C. M., \& Nguyen, H. M. (2020). The role of renewable energy, alternative and nuclear energy in mitigating carbon emissions in the CPTPP countries. Renewable Energy, 161, 278-292. https://doi.org/10.1016/j.renene.2020.07.093

Vo, D. H., Vu, T. N., \& McAleer, M. (2019). Modeling the Relationship between Crude Oil and Agricultural Commodity Prices. Energies, 12(7), 1344.

Vu, T. N., Ho, C. M., Nguyen, T. C., \& Vo, D. H. (2020). The Determinants of Risk Transmission between Oil and Agricultural Prices: An IPVAR Approach. Agriculture, 10(4), 120. https://doi.org/10.3390/agriculture10040120

Wald, E.R. (October 9, 2018). Trump's New Ethanol Rule Explained (And What It Means For Gasoline). Forbes. Retrieved from:

https://www.forbes.com/sites/ellenrwald/2018/10/09/trumps-new-ethanol-rule-wontchange-your-gasoline/\#5bb6315f7d96

Wallander, S., Claassen, R., \& Nickerson, C. (2011). The ethanol decade: an expansion of U.S. corn production, 2000-09. USDA-ERS Economic Information Bulletin, 79. 